\title{
The Effect of House Dust Allergy on the Effectiveness of Allergenic Foods Elimination
}

\author{
Nurul Ima Suciwiyatia1 ${ }^{*}$, Anang Endaryantoab ${ }^{1,2}$, Irwantoab ${ }^{1,2}$ \\ ${ }^{1}$ Department of Pediatrics, Faculty of Medicine Airlangga University, \\ 60132, Surabaya, East Java, Indonesia \\ ${ }^{2}$ Dr. Soetomo General Hospital, 60286, Surabaya, East Java, Indonesia
}

*Corresponding author details: Nurul Ima Suciwiyatia

\begin{abstract}
Food allergy is a primary cause of early manifestations of atopic disease. House dust mites are the main aeroallergens that underlie allergic manifestations. Both of them play a role in the pathogenesis of atopic diseases and cause an impact on the family's economy and health costs. This study was a consecutive sampling retrospective cohort with house dust allergy as an independent variable; food allergy with and without dust allergy with allergenic food elimination, sign \& symptom score, medication score, combination sign \& medication score, visit fee outpatient care, inpatient costs, and total medical expenses as the dependent variable. Data were collected using secondary data from medical records or patient reports via mobile phone messaging applications every month. We averaged data at 3,6,9, and 12 months after the patients were diagnosed with food allergies and undergoing a food elimination diet. The data were analyzed using the Kruskal-Wallis test with a significance level of $<0.05$. We can conclude that house dust allergy influences allergenic food elimination diet effectiveness $(\mathrm{p}=0.001)$.
\end{abstract}

\section{Keywords: food allergy; house dust mite; symptom score; treatment score; cost score}

\section{INTRODUCTION}

Food allergy is the primary cause of early atopic disease manifestations that are mainly caused by house dust mites and food (Perry, 2013, Walczak, Grzelak, et al., 2014, Tanukusumah, 2016, Calderón, 2015, Siregar, 2016). Around $5,9 \%$ of patients in Europe and $10,6 \%$ of children in Jakarta reported having food allergies (Tanukusumah, 2016, Judarwanto, 2016). A study by the University of Indonesia showed that children $(<12$ years old $)$ with pollution and dust allergies had quadrupled in the last 20 years, from 2\% in 1980 and reaching 8\% in 2000 (Quamila, 2017).

Aeroallergen (inhalant allergen) is the primary in-house allergen in the tropic area. This mainly contains Dermatophagoides pteronyssinus and Dermatophagoides farinae (Siregar, 2016). Oral mite anaphylaxis (OMA) may occur in tropical and subtropical Asia with high temperature and humidity (Hossny, 2019). A study showed that around $84 \%$ of children with allergic eczema are sensitive to house dust mites (Klossek, 2012).

A national survey in the United States puts the overall cost of food allergies around $\$ 24.8$ billion per year and direct costs reached US $\$ 11.5$ billion (Gupta, 2013, Cox, 2015). The best treatment for these people is an elimination diet but the effectiveness is affected by exposure to allergens (Ebisawa, 2017). Studies showed that clinical symptoms of $\mathrm{AD}$ may improve after the avoidance of house dust mites but needs more evaluation (Escarrer, 2002, Siregar, 2016). Therefore, the purpose of this study was to determine the effect of house dust allergy on reducing allergy symptoms in children undergoing the elimination of allergenic foods according to the type of food allergy they suffer.

\section{METHODS}

Study design and population

This study is an observational analytic study with a retrospective cohort design followed by a prospective cohort in children with food allergies without house dust allergy and with house dust allergy. We conducted this study in Surabaya by taking secondary data from the allergy outpatient clinic - pediatric immunology and the practice of pediatric allergy consultant pediatrician in Surabaya. This study used data of food allergy children with or without house dust allergies who undergo allergenic food elimination. It was in the medical record at Dr. Soetomo Hospital Surabaya and the practice of allergy consultant pediatrician in Surabaya. They must fulfill the selection criteria (inclusion and exclusion) to participate. The diagnosis of food allergy is made based on a typical history of allergic symptoms and a positive skin prick test result for house dust mite allergens (Bousquet et al., 2008).

\section{Data collection}

We collected data from December 2020 until March 2021. The data source used secondary data from the medical records of the pediatric allergy-immunology outpatient clinic at RSUD dr. Soetomo and his pediatric allergy consultant practice in Surabaya from January 1, 2019, to March 30, 2021. We followed up all participants every three months. We took data on symptoms, treatment, combination score, and treatment. The patient's symptoms were scored as 0 if there were no symptoms, one if mild symptoms, two if moderate symptoms, and three if severe symptoms. The patient's treatments were scored as zero if they had no treatment, scored as one if they used topical/oral antihistamine, two if they used inhalant corticosteroid (regardless of antihistamine use), and three if used oral corticosteroid (regardless of inhalant corticosteroid or antihistamine use). Meanwhile, the combination score data is the sum of the symptom scores and treatment scores. 
Data analysis

The research data will be analyzed using statistical tests using the SPSS device. The baseline characteristics of the research subjects will be presented descriptively in the form of tables listed in the appendix. We used paired T-test comparison analysis if the data distribution was normal or Wilcoxon statistical test if the distribution of the data obtained was abnormal.

\section{Ethical clearance}

Health Research Ethics committee of the Regional General Hospital Dr. Soetomo Surabaya approved the implementation of this research with a letter of exemption number Ref. No: 0347/LOE/301.4.2/II/2021.
Confidentiality of research subjects is well maintained by not mentioning their names, but writing by initials.

\section{RESULTS}

This study analyzed 146 subjects with complete data and meet the inclusion and exclusion criteria. Subjects were divided into two groups. The first group consisted of food allergy patients with house dust allergy and the second group consisted of food allergy patients without house dust allergy. Both of them had undergone allergenic food elimination. Both groups did not have a significant difference in demographic data (Table 1).

TABLE 1: Characteristic of subjects

\begin{tabular}{|c|c|c|c|}
\hline Characteristics & $\begin{array}{l}\text { Food and dust home } \\
\text { allergy }(n=98)\end{array}$ & $\begin{array}{l}\text { Food allergy without dust home } \\
\text { allergy }(n=48)\end{array}$ & P-value \\
\hline Age (years), mean (SD) & $6,33(3,42)$ & $5,9(3,21)$ & \multirow{4}{*}{0.255} \\
\hline \multicolumn{4}{|l|}{ Age category (years) n(\%) } \\
\hline $1-<5$ (toddler) & $34(34,8 \%)$ & $20(41,7 \%)$ & \\
\hline $5-<11$ (children) & $50(50,9 \%)$ & $24(50,1 \%)$ & \\
\hline $11-18$ (teenager) & $14(14,3 \%)$ & $4(8,4 \%)$ & \\
\hline \multicolumn{4}{|l|}{ Gender, n (\%) } \\
\hline Male & $67(68,4 \%)$ & $29(60,4 \%)$ & \multirow{2}{*}{0.238} \\
\hline Female & $31(31,6 \%)$ & $19(39,6 \%)$ & \\
\hline \multicolumn{4}{|c|}{ Nutrition status, mean (SD) } \\
\hline Weight (Kg) & $23,3(9,3)$ & $23,6(8,41)$ & 0.150 \\
\hline High $(\mathrm{cm})$ & $116,4(21,7)$ & $117,3(19,2)$ & 0.222 \\
\hline \multicolumn{4}{|l|}{ Location, $n$} \\
\hline Surabaya & 68 & 37 & \multirow{2}{*}{0.214} \\
\hline Outside Surabaya & 30 & 11 & \\
\hline
\end{tabular}

The majority of patients in the first group had severe symptoms at three months. The number of patients with severe symptoms increased at six months, had no significant change at nine months, and decreased at 12 months. However, the symptom scores change in this group was insignificant over time $(\mathrm{p}=0.480)$. At 3 months, the majority of patients in this group had a treatment score of 3 . The number of patients with a treatment score of 3 increased at 6 months but decreased at 9 and 12 months (Table 2).
This group experienced a significant change in treatment scores over time $(\mathrm{p}=0.000)$.

The majority of patients in the second group had mild symptoms (symptoms score 1). In this group, symptom scores decreased at 9 and 12 months $(p=0.000)$. The majority of patients in the second group were taking oral/topical antihistamine therapy at 6 months. The treatment scores in this group continued to decline significantly at 9 and 12 months $(\mathrm{p}=0.000)$ (Table 2).

TABLE 2: Score progression between group

\begin{tabular}{|c|c|c|c|c|c|c|c|c|c|c|}
\hline & \multicolumn{5}{|c|}{ Food and dust home allergy } & \multicolumn{5}{|c|}{ Food allergy without dust home allergy } \\
\hline & $\begin{array}{c}3 \\
\text { months }\end{array}$ & $\begin{array}{c}6 \\
\text { months }\end{array}$ & $\begin{array}{c}9 \\
\text { months }\end{array}$ & $\begin{array}{c}12 \\
\text { months }\end{array}$ & p-value & $\begin{array}{c}3 \\
\text { months }\end{array}$ & $\begin{array}{c}6 \\
\text { months }\end{array}$ & $\begin{array}{c}9 \\
\text { months }\end{array}$ & $\begin{array}{c}12 \\
\text { months }\end{array}$ & p-value \\
\hline \multicolumn{11}{|c|}{ Symptoms score } \\
\hline 0 & 0 & 0 & 0 & 0 & \multirow{4}{*}{0,480} & 0 & 0 & 25 & 30 & \multirow{4}{*}{0,000} \\
\hline 1 & 0 & 0 & 0 & 10 & & 26 & 30 & 17 & 15 & \\
\hline 2 & 43 & 28 & 28 & 38 & & 16 & 18 & 6 & 3 & \\
\hline 3 & 55 & 70 & 70 & 50 & & 6 & 0 & 0 & 0 & \\
\hline \multicolumn{11}{|c|}{ Treatment score } \\
\hline 0 & 0 & 0 & 0 & 0 & \multirow{4}{*}{0,000} & 0 & 0 & 26 & 35 & \multirow{4}{*}{0,000} \\
\hline 1 & 0 & 0 & 0 & 13 & & 35 & 38 & 16 & 10 & \\
\hline 2 & 40 & 30 & 33 & 37 & & 13 & 10 & 6 & 3 & \\
\hline 3 & 58 & 68 & 65 & 48 & & 0 & 0 & 0 & 0 & \\
\hline
\end{tabular}

Comparative analysis between groups showed that the first and second groups did not have a significant difference in symptom scores at 3 months $(\mathrm{p}=0.096)$ but had significant differences in symptom scores at 6,9 , and
12 months $(p<0,05)$. Although the two groups had no difference in symptom scores, both groups had a significant difference in treatment scores at month $3(\mathrm{p}=0.000)$. That still occurred until the 12 th month $(p=0.000)$ (Table 3$)$. 
This difference in treatment scores also resulted in significant differences in treatment costs between groups at $3,6,9$, and 12 months $(\mathrm{p}<0.05)$ (Table 4).

TABLE 3: Score comparison between group

\begin{tabular}{|c|c|c|c|c|c|c|c|c|c|c|}
\hline & \multicolumn{5}{|c|}{ Symptom score } & \multicolumn{5}{|c|}{ Treatment score } \\
\hline & $\mathbf{0}$ & 1 & 2 & 3 & p-value & $\mathbf{0}$ & 1 & 2 & 3 & p-value \\
\hline \multicolumn{11}{|l|}{3 months } \\
\hline With dust home allergy & 0 & 0 & 43 & 55 & \multirow{2}{*}{0,096} & 0 & 0 & 40 & 58 & \multirow{2}{*}{0,000} \\
\hline Without dust home allergy & 0 & 26 & 16 & 6 & & 0 & 35 & 13 & 0 & \\
\hline \multicolumn{11}{|l|}{6 months } \\
\hline With dust home allergy & 0 & 0 & 28 & 70 & \multirow{2}{*}{0,000} & 0 & 0 & 30 & 68 & \multirow{2}{*}{0,000} \\
\hline Without dust home allergy & 0 & 30 & 18 & 0 & & 0 & 38 & 10 & 0 & \\
\hline \multicolumn{11}{|l|}{9 months } \\
\hline With dust home allergy & 0 & 0 & 28 & 70 & \multirow{2}{*}{0,017} & 0 & 0 & 33 & 65 & \multirow{2}{*}{0,023} \\
\hline Without dust home allergy & 25 & 17 & 6 & 0 & & 26 & 16 & 6 & 0 & \\
\hline \multicolumn{11}{|l|}{12 months } \\
\hline With dust home allergy & 0 & 10 & 38 & 50 & \multirow{2}{*}{0,000} & 0 & 13 & 37 & 48 & \multirow{2}{*}{0,000} \\
\hline Without dust home allergy & 30 & 15 & 3 & 0 & & 35 & 10 & 3 & 0 & \\
\hline
\end{tabular}

TABLE 4: Treatment cost between groups

\begin{tabular}{cccc}
\hline Months & $\begin{array}{c}\text { Food and dust home allergy } \\
\text { Mean (SD) }\end{array}$ & $\begin{array}{c}\text { Food allergy without dust home allergy } \\
\text { Mean (SD) }\end{array}$ & p-value \\
\hline $\mathbf{3}$ & $357.448,9(190.074,92)$ & $171.875(65.967,63)$ & 0.000 \\
$\mathbf{6}$ & $363.869,2(197.493,9)$ & $163.758(61.749,3)$ & 0.024 \\
$\mathbf{9}$ & $363.869,2(197.493,9)$ & $162.692(60.096,9)$ & 0.000 \\
$\mathbf{1 2}$ & $324.765,3(184.177,9)$ & $154.687,5(59.370,9)$ & 0.000 \\
\hline
\end{tabular}

\section{DISCUSSION}

The results of sensitization tests to one or more common allergens in 2016 among schoolchildren approached 40\%$50 \%$ worldwide. (Judarwanto, 2016). Epidemiological studies show a global increase in the prevalence of food allergies worldwide (De Martinis, 2020). Around 5,9\% of patients in Europe and $10,6 \%$ or 7,8 million children in Jakarta reported having food allergies (Tanukusumah, 2016, Judarwanto, 2016). A study in the University of Indonesia showed that children under 12 years old with pollution and dust allergies has quadrupled in the last 20 years (2\% in 1980 to $8 \%$ in 2000) (Quamila, 2017).

D. pteronisynus patch test results were positive in $34 \%$ of AD patients aged 2-10 years. At the age of $<2$ years, sensitization to food allergens is more frequent, while aeroallergens and food are at the age of 2-10 years, while at the age of $>10$ years, aeroallergens are more common (Escarrer, 2002). A Study of children aged 5-14 years in Germany reported a significant relationship between the severity of eczema scores with specific IgE concentrations of house dust mites and cat dander debris. (Gur Cetinkaya \& Sahiner, 2019).

Follow-up of the symptom score showed that the majority of patients in the first group had severe symptoms. Around $56 \%$ patients in this group had symptom score $3(n=55)$ $(\mathrm{p}=0.480)$.

House dust mites are the primary aeroallergens that induce allergic manifestations (Calderón, 2015). Food sensitization and aeroallergens (dust mites, animal dander) are substantial in atopic pathogenesis. It also causes problems for parents and doctors (Siregar, 2016). Food allergy has always been considered the most common trigger factor for anaphylaxis in children.
It can co-occur with other atopic diseases such as atopic dermatitis (AD), allergic rhinitis, asthma, and exacerbate allergic symptoms (Popescu, 2015, Utsch et al., 2017). , Hossny, 2019).

Allergens are divided into inhalant, ingested, injectant, and contact allergens. Aeroallergen (inhalant allergen) is the primary in-house allergen in the tropic area such as Indonesia. This aeroallergen mainly contains Dermatophagoides pteronyssinus and Dermatophagoides farinae (Siregar, 2016). Both are often found on home furnishings such as mattresses, sofas, and carpets (Yang and Zhu, 2017).

Inhaled allergens are divided into indoor and outdoor aeroallergens. Both of these aeroallergens are found in many bedrooms, especially in mattresses, pillows, feather blankets, fur rugs, furry children's toys, and curtains. Others that may act as aeroallergen are Candida albicans, cockroaches also skin flakes from pets of cats, dogs, rabbits, and birds. In Singapore, Blomia tropicalis is a widely available aeroallergen in the home (Gur Cetinkaya \& Sahiner, 2019). Symptoms in the respiratory tract due to food allergies classify as acute or chronic symptoms. IgE plays a role in acute symptoms. The mixture of $\operatorname{IgE}$ and cellular mechanisms play a role in chronic symptoms. It is not easy to identify the occurrence of food-induced allergic rhinitis, because it often appears together with other food allergy symptoms such as asthma, eczema, oral allergy syndromes, urticaria, and gastrointestinal symptoms. People with allergic rhinitis may experience a variety of signs and symptoms such as sneezing, rhinorrhea, nasal congestion, and an itchy nose. Postnasal drip and sometimes cough are other common symptoms. Some sufferers also experience itching in the eyes, throat, palate, and inner ear (deShazo \& Kemp, 2020). 
Then in the 6th month, the symptom score increased with severe symptoms as many as 70 patients. At 9 months, the symptom score did not change or constant. In contrast to the group of food-allergic children without house dust allergy who had also undergone food elimination at the 3rd month $(n=26)$ and 6th month $(n=30)$, the majority had mild symptoms or a score of 1 .

TDR proteases are involved in various immune mechanisms such as destroying the epithelial barrier defense, Th2 cell proliferation, increasing IgE production, and decreasing lung clearance function (Reithofer, 2017). Theoretically, food allergies are more avoidable than inhalant allergies, because, in the modern era, it is almost impossible to avoid all inhalant allergens (Sicherer, 2018). Oral mite anaphylaxis (OMA) had occurred in tropical and subtropical Asia. Both areas had high temperatures and humidity. Mites-contaminated flour often causes OMA (Hossny, 2019).

Food allergies can co-occur with other atopic diseases include allergic rhinitis and asthma via airway inhalation. It shows that aeroallergen cause IgE sensitization in the respiratory tract and food component induce crossreactivity. In adults, about $80 \%$ of cases of food allergy are preceded by sensitization to aeroallergens. In children, around $25 \%$ of cases of food allergy also experience this cross-reaction. Dust mites are the primary in-house allergens. The component of the allergen that most often causes cross-reactivity is tropomyosin (Popescu, 2015). Tropomyosin is an allergen that can be found everywhere, including in shellfish, dust mites (Der p 10), and cockroaches. And there is often cross-reactivity between these allergens because of the homologous amino acid structure even in different species. Shrimp-IgE sensitization can occur due to cross-reaction with other invertebrates-allergen, especially tropomyosin (Farioli, 2017). Patients with shrimp allergy had a high level of IgE against der $\mathrm{p} 1$ and der $\mathrm{p} 10$. The concomitant presence of asthma induced by house dust mites and IgE anti der p1 and der p2 increases the risk of shrimp allergy (Hossny, 2019). Apart from going through the digestive tract, seafood protein can also enter the body through the inhalation of aerosols containing allergens (Rahman, 2012). Wong et al. conducted a study in Asia. They concluded that tropomyosin from mites was the primary sensitizer for shellfish allergy. The incidence is quite high in Asia because Asia has high humidity (Shroba, 2019).

In the Allergic March, eczema due to food allergies preceded the onset of asthma in later life. It shows that children with allergic eczema and positive skin tests with Dermatophagoides pterenosynnus would develop severe asthma compared to children without eczema. (Escarrer, 2002, Cosickic, 2017). Around $84 \%$ of children with allergic eczema are sensitive to house dust mite, evidenced by the results of a skin patch test with house dust mite extract on skin with eczema (Klossek, 2012).

Asthma, allergic rhinitis, and atopic dermatitis have an abnormal basis of IgE response hypersensitivity and tissue-specific inflammation characterized by local infiltration of memory $\mathrm{T}$ lymphocytes, eosinophils, and monocytes/macrophages. T lymphocyte infiltration will be seen with the expression of IL-4, IL-5, and IL-13 in the tissues experiencing acute inflammation. These cytokines play a major role in allergic responses. House dust mite particles may induce anaphylaxis through contaminated food $(\mathrm{Yu}, 2014)$. Among the 95 patients with shrimp allergy, $90.5 \%$ had a positive skin test for house dust mites (Rosenfield, 2017). The presence of asthma induced by house dust mites and positive IgE anti Der p 1,2 and 10 simultaneously increases the risk of shrimp allergy (Farioli, 2017).
Another study states that $84 \%$ of children with atopic dermatitis are sensitive to house dust mites as evidenced by the results of skin patch tests with house dust mite extract on skin with eczema (Klossek, 2012). Inhaled allergens (house dust mites and animal dander) are significantly associated with the severity of atopic dermatitis (Celakovska, 2017).

The last evaluation at 12 months revealed a decrease in symptoms. Although most patients still had severe symptoms scores (50 patients), patients with moderate symptoms increased by 38 persons. In this group, the majority of patients received house dust immunotherapy and education about house dust avoidance and continued to undergo an allergenic food elimination diet. Meanwhile, in the group of food allergy children without house dust allergy who had undergone an allergenic food elimination diet at the 9th and 12th months, 26 patients had no symptoms.

Determination of allergy trigger factors and their avoidance is one of the important factors in the success of allergy treatment. The role of various precipitating factors such as airborne allergens or food allergens has been proven in various studies (Zakiudin, 2002).

A definite diagnosis of food allergy can only be confirmed by the Double-Blind Placebo Control Food Challenge (DBPCFC) or by eliminating food provocations. The best treatment for people with food allergies is to avoid the food causing it (elimination diet). The emergence of allergy symptoms is not only influenced by the cause of the allergy (allergen) but is also influenced by the trigger of the allergy (Judarwanto, 2011, Ebisawa, 2017). Specific therapy for food hypersensitivity is certain to avoid the cause (elimination diet) (Judarwanto, 2011).

A study conducted by Hankin et al. in 2013 found that there was a significant decrease in the average frequency of outpatient, inpatient, and treatment in allergic rhinitis children who received immunotherapy and those who did not. Averages and total cost of overall treatment (immunotherapy and other therapy) in allergic rhinitis children for 18 months decreased significantly.

Food allergy patients with dust allergy had higher medical costs when compared to the food allergy group without house dust allergy who had undergone allergenic food elimination.

Food allergies in children have an impact on the family's economy and health costs. Direct costs incurred to treat the disease (doctor, hospital fees, laboratory test, and pharmacological therapy) and transportation. Indirect costs include non-health costs related to illness, such as the cost of not attending school and work and decreased productivity due to illness. Other indirect costs include the time spent by both the patient and the person caring for the patient during illness (Blaiss, 2010).

A national survey of parents of children with food allergies in the United States puts the overall cost of food allergies at an estimated $\$ 24.8$ billion per year $(95 \% \mathrm{CI}, \$ 20.6$ \$29.4) (Gupta, 2013). A survey in the United States (USA) estimated that the direct costs of allergic colds due to dust mites reached US $\$ 11.5$ billion, of which 59\% came from prescription treatments (Cox, 2015.) Treatment costs contributed the most $(46 \%)$ to the total direct costs (Ngamphaiboon et al., 2012).

Allergic rhinitis accounts for $2.5 \%$ of all doctor visits, 2 million lost school days, 6 million lost workdays, and 28 million restricted workdays per year (deShazo \& Kemp, 2020). 
Asthma incidence and prevalence are increasing in some countries. The average cost per patient per year of all asthmatic patients (intermittent, mild, moderate, and severe asthma) in Europe is \$USD 1,900 and \$USD 3,100 in the USA(Nunes, 2017). The cost of treating atopic dermatitis reaches \$576-\$1,097 per year (Bhanegaonkar, 2014).

The Kruskal-Wallis test SPSS software showed that the asymp sig is 0.000 and $<0.05$, so the hypothesis of this study can be accepted. It means that house dust allergy influences the effectiveness of allergenic food elimination, treatment, and costs.

Theoretically, food allergies are more avoidable than inhalant allergies, because, in the modern era, it is almost impossible to avoid all inhalant allergens(Sicherer, 2018). Many factors play a role, both exogenous or endogenous factors or a combination of both. Genetic factors are endogenous factors. Exogenous factors such as food and aeroallergens may trigger $\mathrm{AD}$, allergic rhinitis, and asthma There is still disagreement about food as a cause of allergy reaction but allergy symptoms may improve if they avoid allergenic food. Inhaled allergens (such as house dust mites) play a role in the pathogenesis of $\mathrm{AD}$, especially in children. It is based on several clinical observations, skin tests, and high specific IgE. There is an improvement in clinical symptoms of AD after the avoidance of house dust mites (Escarrer, 2002, Siregar, 2016).

The etiology and pathogenesis of this disease is a complex interaction between genetic susceptibility. This complex interaction results in skin barrier defect, innate immune system defect, and enhanced immunologic responses to allergens and microbial antigens. Genetic factors have an important role, but environmental factors also play a role. (Leung, 2012).a

Allergens classify into inhalant, ingestion, parenteral, and contact allergens. Allergens in the air (inhalants) can come from inside and outside the home. Some examples of allergic symptoms are allergic rhinitis, bronchial asthma, and atopic dermatitis (Baratawijaya, 2009). Avoidance of airborne allergens that trigger atopic dermatitis may control atopic dermatitis symptoms. By clearing the mites from the patient's environment, it can improve clinical symptoms without other treatment. If the patient returns, the disease will exacerbate within 1-2 days.

Dust mites can cause airway inflammation that is influenced by dendritic cells. They act as professional antigen-presenting cells and play an important role in the allergy sensitization phase of this airway inflammation. After desquamation of the epithelial cells and disruption of the tight junctions by the TDR, dendritic cells (DCs) can identify and process antigens. And present these antigens to major histocompatibility complex class II molecules to naive T lymphocytes in local lymph nodes. This shift causes a cascade of T helper 2 (Th2) and causes an inflammatory response by cytokine mediators (Yu, 2014). Several important components of dust mites such as Der p 1, a cysteine protease, can bind specific IgE on basophils and mast cells and can have highly potent proteolytic activity on the epithelium, resulting in a range of specific and nonspecific responses. Der p2 and its specific IgE are highly correlated with allergic hypersensitivity in patients with asthma, atopic dermatitis, and allergic rhinitis. Der p3 can induce cytokine release from human lung epithelial cells (Vogel, 2015). OAS (oral allergy syndrome) or PFAS (pollen food allergy syndrome) are symptoms of allergies to some foods in patients who have allergies to aeroallergens (pollen, dust, etc). The most common symptom is oral-pharyngeal pruritus.
Other symptoms include tightness in the throat, difficulty swallowing, nausea, dysphonia, an itchy nose, and itchy ears. In addition, there is a relationship between early allergen sensitization and cross-reactivity (Carlson, 2019). The proteolytic activity of house dust mite allergen (TDR) affects various innate immune response pathways, increasing the severity and chronicity of the allergic disease. TDR bioactivity is a potential therapeutic target and has been clinically developed as immunotherapy (Thomas, 2015). Studies have reported that indoor house dust mite levels are associated with the severity of skin lesions. The mite's bio-reactive molecules consist of proteins and endotoxins derived from the body and feces. Various extracts from house dust mites have been used for diagnostic tests, immunotherapy, and induction of atrophic dermatrophy-like lesions in mice (Zhang, 2017; Moore, Morris-Jones, and Nabarro, 2020).

\section{CONCLUSIONS}

Symptom scores, treatment scores, and medication costs decreased in children without house dust allergy, increased in those with house dust allergy who underwent food allergenic elimination at 3, 6, 9, and 12 months after treatment. So both have significant symptom scores, treatment scores and treatment costs different.

\section{ACKNOWLEDGEMENTS}

Authors would like to thank the Lecturer, Colleague, Nurses and Paediatrics Residents in Department of Paediatrics, Dr. Soetomo General Hospital Surabaya, Indonesia.

\section{REFERENCES}

[1] Abdel Rahman AM. Characterization of Seafood Proteins Causing Allergic Diseases. Allerg Dis Highlights Clin Mech Treat. 2012;679-81.

[2] Ahadiah TH, Sumantri RD. Rinitis alergi pada anak. Media perhati $2000 ; 6: 14-21$

[3] Albert JO, Marjolein S de Bruin-Weller, Ingrid T,Zana TP, Rob CA, Jan GR de Monchy, et al. 2002. Effect of mat- tress encasings on atopic dermatitis outcome measures in a double-blind, placebo-controlled study : The Dutch mite avoidance study. J Allergy Clin Immunol. 110:500-6.

[4] Anvari S, Miller J, Yeh C, Davis CM. 2019. IgEMediated Food Allergy. Clinical Reviews in Allergy \& Immunology. 57, 244-60.

[5] Bernstein, J.A. 2000. Cost-benefit analysis for allergen immunotherapy. Immunol Allergy Clin. 20:593-607.

[6] Beyer K. 2012. A European perspective on immunotherapy for food allergy. J Allergy Clin Immunol. 129(5):1179-84.

[7] Bhanegaonkar A, Horodniceanu EG, Ji X, Detzel P, Botteman MF. 2014. Burden of Atopic Dermatitis in Indonesia, Malaysia, and Singapore: Estimates from a Mathematical Model. Value Heal. 17:778.

[8] Blaiss, M.S. 2010. Allergic rhinitis: direct and indirect costs. Allergy Asthma Proc. 31, 375-80.

[9] Canonica, G.W., C.E. Baena-Cagnani, J. Bousquet, P.J. Bosuquet, R.F. Lockey, H.J. Mallingm G. Passalacqua, P. Potter, and E. Valovirta. 2007. Recommendations for standardization of clinical trials with Allergen Specific Immunotherapy for respiratory allergy. A statement of a World Allergy Organization (WAO) taskforce. Allergy. 62, 317-24. 
[10] Carlson G, Coop C. Pollen food allergy syndrome (PFAS): A review of current available literature. Ann Allergy, Asthma Immunol. 2019;123:359-65.

[11] Čelakovská J, Bukač J. 2017. Severity of atopic dermatitis in relation to food and inhalant allergy in adults and adolescents. Food Agric Immunol. 28:121-33

[12] Clark J and R. Schall. 2007. Assessment of combined symptom and medication scores for rhinoconjunctivitis immunotherapy clinical trials. Allergy. $62,1023-8$

[13] Colloff, M.J. 2009. Dust Mites. CSIRO publishing. Collingwood. 45-100.

[14] Ćosickić A, Skokić F, Selimović A, Mulić M, Suljendić S, Dedić N, et al. 2017. Development of respiratory allergies, asthma and allergic Rhinits in children with atopic dermatitis. Acta Clin Croat. 56:308-17.

[15] Cox, L. 2015. Allergy Immunotherapy in reducing healthcare cost. Curr Opin Otolaryngol Head Neck Surg. 23, 247-54.

[16] De Martinis M, Sirufo MM, Suppa M, Ginaldi L. 2020. New perspectives in food allergy. Int J Mol Sci. 21, 1-21.

[17] deShazo, R.D., and S.F. Kemp. 2020. Allergic Rhinitis: Clinical manifestations, epidemiology, and diagnosis [Internet]. New York: Wolters Kluwer [updated 2020 Jan 20th; cited 2020 June 1st]. Available from:https://www.uptodate.com/contents/allergicrhinitis-clinical-manifestationsepidemiology-anddiagnosis.

[18] Ebisawa M, Ito K, Fujisawa T. 2017. Japanese guidelines for food allergy. Allergol Int. 66, 248-64.

[19] Eifan, A.O., T. Akkoc, A. Yildiz, S. Keles, C. Ozdemir N.N. Bahceciler, and I.B. Barlan. 2010. Clinical efficacy and immunological mechanisms of sublingual and subcutaneous immunotherapy in asthmatic/rhinitis children sensitized to house dust mite: an open randomized controlled trial. Clin Exp Allergy. 40:922-32.

[20] Endaryanto A. Implikasi Klinis Imunologi Alergi Dalam Manajemen Anak Alergi. pertama. Surabaya: airlangga university press; 2015. 16-88 p.

[21] Erwin EA, Custis NJ, Satinover SM, Perzanowski MS, Woodfolk JA, Crane J, et al. 2005. Quantitative measurement of IgE antibodies to purified allergens using streptavidin linked to a high-capacity solid phase. J Allergy Clin Immunol. 115:1029-35.

[22] Escarrer Jaume M, Muñoz-López F. 2002 Importancia de los aeroalergenos en la etiopatogenia de la dermatitis atópica. Allergol Immunopathol (Madr). 30:126-34.

[23] Farioli L, Losappio LM, Giuffrida MG, Pravettoni V, Micarelli G, Nichelatti M, et al. 2017. Mite-Induced Asthma and IgE Levels to Shrimp, Mite, Tropomyosin, Arginine Kinase, and der $\mathrm{p} 10$ Are the Most Relevant Risk Factors for Challenge-Proven Shrimp Allergy. Int Arch Allergy Immunol. 174:133-43.

[24] Fernández-Caldas, E., L. Puerta, L. Caraballo, and R.F. Lockey. 2008. Mite allergens. In: Lockey, R.F., Ledford, D. (ed.). Allergens and allergen immunotherapy. Informa Healthcare USA. New York. 161-82.
[25] Fleischer DM, Bock SA, Spears GC, Wilson CG, Miyazawa NK, Gleason MC, et al. 2011. Oral food challenges in children with a diagnosis of food allergy. J Pediatr. 158:578-583.e1.

[26] Frew, A.J., C. Ljorring, H. Wolf, E. Wustenberg, S.R. Durham, C.J. Corrigan, R.J. Powell, and O. Pfaar. 2018. UK Immunotherapy Study: Reanalysis by a combined symptom and medication score. J Allergy Clin Immunol. 142, 1998-9.

[27] Gupta R, Holdford D, Bilaver L, Dyer A, Holl JL, Meltzer D. 2013. The economic impact of childhood food allergy in the United States. JAMA Pediatr.167, 1026-31.

[28] Gür Çetinkaya P, Murat Şahiner Ü. 2019. Childhood atopic dermatitis: Current developments, treatment approaches, and future expectations. Turkish J Med Sci. 49:963-84.

[29] Gregory, L.G. and C.M. Lloyd. 2011. Orchestrating house dust mite-associated allergy in the lung. Trends Immunol. 32, 402-11.

[30] Helmark TI, Segelmark M. 2014. Diagnosis and Classification of Goodspastures disease (anti GBM). J Autoimmun. Feb-Mar;48-49:108-12.

[31] Hossny E, Ebisawa M, El-Gamal Y, Arasi S, Dahdah L, El-Owaidy R, et al. 2019. Challenges of managing food allergy in the developing world. World Allergy Organ J. 12:100089.

[32] Irawati N, Abdilah F. Patofisiologi dan diagnosis alergi makanan. Otorhinolaryngologica Indonesiana 2005; $35: 26-39$

[33] Jeffrey D. Miller 2018. The Role of Dust Mites in Allergy. Clinical Reviews in Allergy \& Immunology. $20,345-8$

[34] Judarwanto W. Alergi debu, dingin atau alergi makanan. Posted : 14 Juni 2011. Available from : http://kesehatan.kompasiana.co $\mathrm{m} /$ medis/2011/02/25/alergidebu-dingin-ataualergimakanan. Accessed October 14, 2011

[35] Karakoc-Aydiner, E., A.O. Eifan, S. Baris, E. Gunay, H. Akturk, T. Akkoc, N.N. Bahceciler, and I.B. Barlan. 2015. Long-term effect of sublingual and subcutaneous immunotherapy in dust mite-allergic children with asthma/rhinitis: a 3-year prospective randomized controlled trial. J Investig Allergol Clin Immunol. 25:334-42.

[36] Klossek, J. M., I. Annesi-Maesano, C. Pribil and A. Didier. 2012. "The burden associated with ocular symptoms in allergic rhinitis." Int Arch Allergy Immunol. 158:411-7.

[37] Krishna MT, Huissoon AP. 2011. Clinical immunology review series: an approach to desensitization. Clin Exp Immunol. 163(2):131- 46.

[38] Kurihara K. Immunotherapy for food allergy. 2010. Allergol Int. 59(1):9-14.

[39] Lang AC, van der Spuy DA, Goddard E, Terblanche AJ, Kriel M, Gray CL, et al. Elimination diets and dietary interventions for the management of food allergies. South African Med J. 2015;105:71-2. 
[40] Langley S], Goldthorpe S, Craven M, Woodcock A Custovic A .2005. Relationship between exposure to domestic allergens and bronchial hyperresponsiveness in non-sensitised, atopic asthmatic subjects. Thorax. 60, $17-21$.

[41] Luo J, Li Y, Gong R. 2010. The mechanism of atopic march may be the social ebvent of cell and molecules (Review). Int J Mol Medicine: 26:779-85.

[42] Maitre S Maniu CM, Buss G, Maillard MH, et al. 2014. Food allergy or food intolerance? Rev Med suisse: 10 (426):846-50.

[43] Martinolli F, Carraro S, Berardi M, Ferraro V, Baraldi E, Zanconato S. 2014. Immunotherapy for food allergies in children. Curr Pharm Des. 20(6):906-23.

[44] Mousallem T, Burks AW. 2012. Immunology in the clinic review series; focus on allergies: immunotherapy for food allergy. Clin Exp Immunol. 167(1):26-31.

[45] Natalia, D. 2015. Peranan alergen tungau debu rumah (Der p 1 dan Der p 2) dalam reaksi alergi. CDK. 42, 251-5.

[46] Ngamphaiboon, J., T. Kongnakorn, P. Detzel, K. Sirisomboonwong, and R. Wasiak. 2012. Direct medical costs associated with atopic diseases among young children in Thailand. J Med Econ. 15. 1025-35.

[47] Nowak-Wegrzyn A, Katz Y, Mehr SS, Koletzko S. 2015 Non-IgE medited gastrointestinal food allergy. I Allergy Clin Immunol. 135, 1114- 24.

[48] Nunes C, Pereira AM, Morais-Almeida M. 2017. Asthma costs and social impact. Asthma Res Pract. 3, 1-11.

[49] Palomares 0 . The role of regulatory t cells in IgEmediated food allergy. J Investig Allergol Clin Immunol. 2013;23:371-82.

[50] Perry TT, Pesek RD. 2013. Clinical manifestations of food allergy. Pediatr Ann. 42:96-101.

[51] Pfaar, O., P. Demoly, R. Gerth van Wijk, S. Bonini, J. Bousquet, G.W. Canonica, and S.R Durham. 2014 Recommendations for the standardization of clinical outcomes used in allergen immunotherapy trials for allergic rhinoconjunctivitis: an EAACI Position Paper. Allergy. 69, 854-67.

[52] Popescu F-D. 2015. Cross-reactivity between aeroallergens and food allergens. World J Methodol. 5:31.

[53] Reithofer M, Jahn-Schmid B. 2017. Allergens with protease activity from house dust mites. Int J Mol Sci. $18,11-3$.

[54] Rondon, C., N. Blanca-Lopez, P. Campo, C. Mayorga, R. Jurado-Escobar, M.J. Torres, G. Canto, and M. Blanca. 2018. Specific immunotherapy in local allergic rhinitis: A randomized, double-blind placebocontrolled trial with Phlum pretense subcutaneous allergen. Allergy. 73:905-15.

[55] Rosenfield L, Tsoulis MW, Milio K, Schnittke M, Kim H. 2017. High rate of house dust mite sensitization in a shrimp allergic southern Ontario population. Allergy, Asthma Clin Immunol. 13:1-7.

[56] Sánchez-Borges, M., E. Fernandez-Caldas, W. R Thomas, M. D. Chapman, B. W. Lee, L. Caraballo, N. Acevedo, F. T, et al. 2017. "International consensus (ICON) on: clinical consequences of mite hypersensitivity, a global problem. The World Allergy Organization journal. 10, 14-8.
[57] Savage, J. and C. B. Johns. 2015. "Food allergy: epidemiology and natural history. Immunology and allergy clinics of North America. 35, 45-59.

[58] Shamji, M.H and S.R. Durham. 2017. Mechanisms of allergy immunotherapy for inhaled allergens and predictive biomarkers. J Allergy Clin Immunol. 140, 1485- 98.

[59] Shroba J, Rath N, Barnes C. Possible Role of Environmental Factors in the Development of Food Allergies. Clin Rev Allergy Immunol. 2019;57:303-11.

[60] Sicherer SH, Sampson HA. 2010. Food allergy. J Allergy Clin Immunol. 125:S116-25.

[61] Sicherer SH, Sampson HA. 2018. Food allergy: A review and update on epidemiology, pathogenesis, diagnosis, prevention, and management. J Allergy Clin Immunol. 141:41-58.

[62] Sicherer SH, Sampson HA. 2014. Food allergy: epidemiology, pathogenesis, diagnosis, and treatment. J Allergy Clin Immunol.133, 291-307.

[63] Siregar SP. 2016. Peran Alergi Makanan dan Alergen Hirup pada Dermatitis Atopik. Sari Pediatr. 6:155.

[64] Sundaru H. 2006. House dust mite allergen level and allergen sensitization as risk factors for asthma among student in central Jakarta. Med J Indones. 15, 55-9.

[65] Tanukusumah M, Kurniati N, C NA. 2016. Prevalensi Alergi Makanan pada Anak Usia Kurang dari 3 Tahun di Jakarta Berbasis Survei dalam Jaringan / Online. Sari Pediatr. 16:365.

[66] Thomas, W.R. 2015. Hierarchy and molecular properties of house dust mite allergens. Allergol Int. $64,304-11$

[67] Utsch, L., A. Logiantara, R. van Ree and L. S. van Rijt. 2017. "Experimental food allergy to peanut enhances the immune response to house dust mite in the airways of mice. Clin Exp Allergy. 47, 121-8.

[68] Valenta R, Hochwallner H, Linhart B, Pahr S. 2015. Food allergies: The basics. Gastroenterology. 148, 1120-31.

[69] Van Splunter M, Liu L, Joost van Neerven RJ, Wichers HJ, Hettinga KA, de Jong NW. Mechanisms underlying the skin-gut cross talk in the development of igemediated food allergy. Nutrients. 2020;12:1-20.

[70] Vogel P, Dal Bosco SM, Ferla NJ. Ácaros Y Las Consecuencias Sobre La Salud Humana. Nutr Hosp. 2015;31:944-51.

[71] Vasar M, Julge K, Bjoksto B. 2000. Development of atopic sensitization and allergic diseases in early childhood. Acta Paediatr. 89:523-7.

[72] Walczak, M., T. Grzelak, M. Kramkowska and K. Czyżewska. 2014. "Food allergies in children-aspects of epidemiology and diet management. Journal of Medical Science. 83, 255-259.

[73] Yang, L. and R. Zhu. 2017. Immunotherapy of house dust mite allergy. Human vaccines \& immunotherapeutics. 13, 2390-6.

[74] Yu SJ, En-chih Liao and J-JT. Asia Pacific allergy. House dust mite allergy Environ Eval Dis Prev. 2014;4:241-52 